\title{
PRESIDENTIAL CONSTITUTIONAL INTERPRETATION, SIGNING STATEMENTS, EXECUTIVE POWER, AND ZIVOTOFSKY
}

HENRY L. CHAMBERS, JR. *

INTRODUCTION.

I. The PResidential OATH, the TAKe Care Clause,

AND INTERPRETATION.

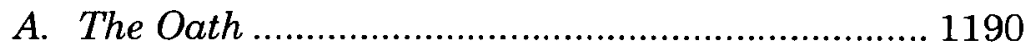

B. The Take Care Clause ........................................... 1191

C. Clearly Unconstitutional Laws .......................... 1193

II. Constitutional Signing STATEMENTS AND VETOES 1195
A. Refusal to Enforce Law 1195

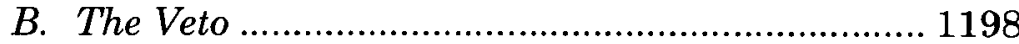
C. Implications ......................................................... 1200

III. INTERPRETING THE CONSTITUTION AS A LEGAL

DOCUMENT OR AS A POLITICAL DOCUMENT ................. 1201

A. Constitution as a Legal Document ...................... 1202

B. The Constitution as a Political Document........... 1204

C. Filling the Constitution's Interstices................... 1207

D. Constitutionality and Unconstitutionality .......... 1209

E. Who Interprets the Constitution............................ 1212

IV. DEPARTMENTALISM AND JUDICIAL REVIEW ................. 1214

A. The Scope of Congressional Constitutional Interpretation....................................................... 1215

B. The Scope of the Supreme Court's Constitutional Interpretation ....................................................... 1216

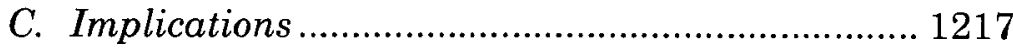

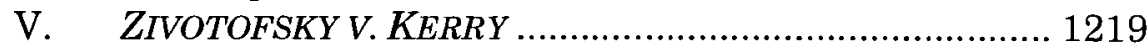

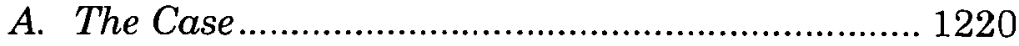

B. Zivotofsky, Constitutional Text, and Constitutional Principles .................................... 1222

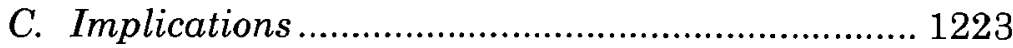

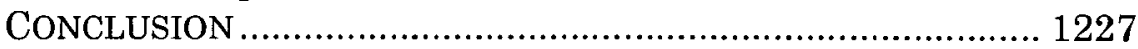

* Professor of Law, University of Richmond. The author thanks Kelsey Martin for her exceptional research assistance. 


\section{INTRODUCTION}

As noted in Dean Harold H. Bruff's superb book, Untrodden Ground: How Presidents Interpret the Constitution, the President of the United States routinely interprets the United States Constitution. ${ }^{1}$ How aggressively the President should interpret the Constitution is subject $t$ s significant dispute. This Article considers that issue in the context where the President is the most aggressive, i.e., when threatening to decline to enforce a federal statute because the President believes the statute is unconstitutional. Such action has become increasingly common in the past few decades as Presidents have increasingly promulgated constitutional signing statements, ${ }^{2}$ official statements explaining how the President will enforce or decline to enforce enacted legislation based on the President's opinion regarding the legislation's constitutionality. ${ }^{3}$ The latitude the President has or should have to interpret the Constitution is particularly important in areas such as foreign policy and national defense, where the President claims plenary constitutional authority. ${ }^{4}$ Whether constitutional signing statements fit comfortably within our constitutional structure or are in derogation of that structure may depend on how aggressively the President interprets the Constitution.

Presidential constitutional interpretation may appear to be inconsistent with our constitutional structure, if constitutional interpretation is the primary or sole province of the Supreme Court. ${ }^{5}$ However, constitutional interpretation is not the sole

1. See Harold H. BrufF, UnTRodden GRoUnd: How Presidents INTERPRET THE CONSTITUTION 1 (2015) (discussing Presidents' constant interpretation of the Constitution).

2. See Peter M. Shane, Madison's nightmare: How Executive Power THREATENS AMERICAN DEMOCRACY 135 (2009) (discussing the significant increase of constitutional signing statements since the Reagan Administration).

3. See Christopher S. Kelley, The Significance of the Presidential Signing Statement, in EXECUTING THE CONSTITUTION: PUTTING THE PRESIDENT BACK INTO THE CONSTITUTION 74 (Christopher S. Kelley ed., 2006) (discussing constitutional signing statements).

4. See James P. Pfiffner, Power Play: The Bush Presidency and the CONSTITUTION 194-95 (2008) (describing and criticizing some of President George W. Bush's signing statements that relied on the broad interpretation of executive power).

5. See Cooper v. Aaron, 358 U.S. 1, 16-17 (1958) (noting that the Supreme Court is the supreme interpreter of the Constitution); Marbury v. Madison, 5 U.S. (1 Cranch) 137, 177 (1803) ("It is emphatically the province and duty of the 
province of the Court. Though the Court has the final word regarding the Constitution's meaning, the President may be obligated to interpret the Constitution. The President's duty to "take Care that the Laws are faithfully executed"6 appears to trigger the power, and possibly the responsibility, to interpret the Constitution. The faithful execution duty requires that the President enforce the Constitution and federal statutory law, as both are the supreme law of the land. ${ }^{7}$ However, when the Constitution and statutory law conflict, statutory law must yield. ${ }^{8}$ Determining whether the Constitution and statutory law conflict appears to require that the President interpret both. How the President should determine whether statutory law is unconstitutional and whether he should decline to enforce statutory law based on that determination are subject to debate. ${ }^{9}$

Presidential commentary on legislation is not new or novel. ${ }^{10}$ Presidents have issued non-constitutional signing statements since the early days of the Republic and continue to do so. ${ }^{11}$ However, the use of such statements has evolved ${ }^{12}$ and

judicial department to say what the law is."); CHRISTOPHER N. MAY, PRESIDENTIAL DEFIANCE OF "UNCONSTITUTIONAL" LAWS: REVIVING THE ROYAL PREROGATIVE 38 (1998) ("[T] his power to declare laws unconstitutional was given to the courts, not to the President."); Faith Joseph Jackson, The Constitutionality of Presidential Signing Statements: A Note on H.R. 5993 - The Presidential Signing Statements Act of 2008, 35 J. LEGIS. 1, 4 (2009) (suggesting that judicial power includes power to interpret the Constitution).

6. U.S. CONST. art. II, $\S 3$.

7. See id. art. VI ("This Constitution, and the Laws of the United States which shall be made in Pursuance thereof; and all Treaties made, or which shall be made, under the Authority of the United States, shall be the supreme Law of the Land[.]").

8. Though federal law passed pursuant to the Constitution is the supreme law of the land, an unconstitutional federal statute is no law at all. See Norton v. Shelby Cty., 118 U.S. 425, 442 (1886) ("An unconstitutional act is not a law; it confers no rights; it imposes no duties; it affords no protection; it creates no office; it is, in legal contemplation, as inoperative as though it had never been passed.").

9. Compare MAY, supra note 5, at 73-75 (castigating a refusal to enforce federal law based on presidential constitutional interpretation), with Saikrishna Bangalore Prakash, The Executive's Duty to Disregard Unconstitutional Laws, 96 GEO. L.J. 1613 (2008) (encouraging the refusal to enforce federal law based on presidential constitutional interpretation).

10. Signing statements can have many uses. See The Legal Significance of Presidential Signing Statements, 17 Op. O.L.C. 131, 131 (1993) (noting that signing statements can be used to explain the effects of the subject legislation, to direct executive branch officials how to execute the law, and to note that the President will not execute the legislation to the extent he thinks it unconstitutional) [hereinafter Dellinger OLC Memo].

11. See Kelley, supra note 3, at 75-76 (asserting that James Monroe was the 
become more common. ${ }^{13}$ Historically, signing statements included commentary about the subject legislation, such as praise for its aims and suggestions about statutory interpretation and implementation. ${ }^{14}$ More recently, they have been issued for broader purposes, including to augment or change legislative history. ${ }^{15}$ That use is somewhat controversial, but does not trigger the same constitutional issues that using a statement to justify a refusal to enforce a law does. ${ }^{16}$

Constitutional signing statements are controversial, in part, because the Constitution does not indicate how much latitude the President should have to decline to enforce legislation based on his belief that legislation is unconstitutional. ${ }^{17}$ Arguably, the President should interpret the Constitution sparely, with presidential interpretation straying as little as possible from constitutional text or the President's best guess regarding the Supreme Court's presumed interpretation of the relevant constitutional text. ${ }^{18}$

first President to issue a signing statement); see also Curtis A. Bradley \& Eric A. Posner, Presidential Signing Statements and Executive Power, 23 ConsT. COMMENT. 307, 312-16 (2007) (discussing history of signing statements).

12. See SHANE, supra note 2, at $132-33$ (noting that signing statements are not rare, but constitutional signing statements were fairly rare before President George W. Bush's Administration).

13. See Kelley, supra note 3 , at 76 (noting escalation of signing statements between Presidents Nixon and Clinton).

14. See MAY, supra note 5, at 73-75 (providing the history of signing statements and noting their various uses); PFIFFNER, supra note 4, at 198 (discussing the history of signing statements and their evolution from mere statements on legislation to vehicles for voicing constitutional concerns about legislation in the second half of twentieth century); Kelley, supra note 3, at 74 (noting three kinds of signing statements: constitutional, political, and rhetorical).

15. See PHILliP J. CoOPER, By ORder of THE PREsident: The USE AND ABUSE OF EXECUTIVE DIRECT ACTION 210-11 (2002) (noting use of signing statements as attempt to create or fix legislative history).

16. See PFIFFNER, supra note 4, at 208-11 (suggesting that signing statements should not be used to determine legislative intent notwithstanding attempts to do so); see also Dellinger OLC Memo, supra note 10, at 131 (noting arguments for and against using presidential signing statements as a form of legislative history).

17. See Jackson, supra note 5, at 5 (noting that the American Bar Association was sufficiently troubled about the use of signing statements to convene a task force to study the issue); cf. MAY, supra note 5, at 37 ("The Constitution does not give the President a power to suspend the laws, not even when the chief executive may think that a particular law is unconstitutional.").

18. See Dellinger OLC Memo, supra note 10, at 133 (suggesting that presidential constitutional interpretation can be analogized to Supreme Court interpretation at times). 
Conversely, the President-as a coequal constitutional actorcould be as free to interpret the Constitution and act on that interpretation as any other constitutional actor, including the Supreme Court, when the President deems such interpretation necessary to guide the President in discharging his or her constitutional duties. ${ }^{19}$ Whether the expanding claims of recent Presidents regarding the chief executive's freedom to interpret the Constitution and ignore portions of legislation he believes unconstitutional are reasonable depends, in part, on how much latitude constitutional actors, including the President, believe the Constitution gives the President to act in such situations. ${ }^{20}$ This is particularly important as the use of constitutional signing statements can augment executive power and functionally alter the Constitution's separation of powers structure. ${ }^{21}$

The appropriate level of aggression in presidential constitutional interpretation is a live issue. Presidential constitutional interpretation was at the core of Zivotofsky $v$. Kerry, ${ }^{22}$ a recent Supreme Court case that involved the clash of executive power and legislative power in the foreign policy area. ${ }^{23}$ The case hinged on whether the President has the exclusive authority to recognize foreign nations. ${ }^{24}$ More narrowly, the decision focused on Congress's constitutional

19. See Prakash, supra note 9, at 1645 ("[T] he Constitution never requires the President to accept the constitutional conclusions of his co-equal branches."). For an elegant discussion of the use or non-use of text in constitutional interpretation, see David A. Strauss, Foreword: Does the Constitution Mean What it Says?, 129 HARV. L. REV. 2 (2015).

20. See Curtis A. Bradley \& Trevor W. Morrison, Presidential Power, Historical Practice, and Legal Constraint, 113 COLUM. L. REV. 1097, 1098 (2013) ("Especially when the text of the Constitution is unclear or does not specifically address a particular question, the way in which the government has operated over time can provide what Justice Frankfurter famously called a constitutional 'gloss' on Presidential power.").

21. See COOPER, supra note 15, at 201 (noting that the way that the signing statement has come to be used since President Reagan took office is aggressive and evolving); PFIFFNER, supra note 4, at 200 (noting the Reagan administration's strategic use of signing statements to increase presidential power).

22. 135 S. Ct. 2076 (2015).

23. Id. at 2081 (noting that foreign policy is often left to the political branches to resolve with the judicial branch having a limited role). For an extended discussion of Zivotofsky's role in altering the foreign policy landscape, see Jack Goldsmith, Zivotofsky II as Precedent in the Executive Branch, 129 HARV. L. REV. 112 (2015).

24. Zivotofsky, $135 \mathrm{~S}$. Ct. at 2081 (explaining that the pertinent issues in the case relate to the degree to which the President exercises exclusive power to recognize sovereign nations). 
authority to pass a law that included a provision that appeared to require that the President recognize Israel as having sovereign control over Jerusalem. ${ }^{25}$ In the wake of the legislation's passage, President George W. Bush issued a signing statement deeming that section of the law unconstitutional if it required that the President recognize Israel's sovereignty over Jerusalem. ${ }^{26}$ Rather, he noted that he would interpret the statute to provide the President the option to deem Jerusalem as a part of Israel if the President so chose. ${ }^{27}$ The case did not directly address the signing statement in siding with the President. The constitutionality of the legislation-rather than the appropriateness of the signing statement-was at issue, though the case may help illuminate how a President may interpret the Constitution and whether the President should act on that interpretation.

This Article explores whether the President should interpret the Constitution aggressively and, if so, whether the President should act on such aggressive interpretations. Part I examines whether the presidential oath and other constitutional duties obligate the President to interpret the Constitution. Part II considers constitutional signing statements as the manifestation of an aggressive approach to presidential constitutional interpretation. Part III considers whether the Constitution is a legal document or a political document, and how that determination might affect how aggressive the President should be when interpreting the Constitution. Part IV considers how the Supreme Court's and Congress's constitutional interpretations might constrain presidential constitutional interpretation or suggest restrained presidential constitutional interpretation. Part $\mathrm{V}$ considers Zivotofsky $v$. Kerry and whether it provides the President additional arguments to support an aggressive approach to constitutional interpretation, particularly when considering matters related to executive power. ${ }^{28}$

25. Id. at 2082 .

26. Id.

27. Id.

28. Id. at 2076 . 


\section{The PREsidential OATH, The TAKe CARE Clause, AND INTERPRETATION}

The Constitution requires the President to interpret the Constitution and may allow him to act based on that interpretation. The presidential oath of office requires that the President "faithfully execute the Office of President of the United States" and "preserve, protect and defend the Constitution."29 The oath requires that the President ensure that presidential and other governmental actions comport with and support the Constitution. ${ }^{30}$ The Constitution also requires that the President "take Care that the Laws be faithfully executed." 31 Given that the Constitution is the supreme law of the land, the Take Care Clause appears to require that the President interpret the Constitution to determine whether to execute laws that he believes are unconstitutional. Conversely, the Take Care Clause could require that he execute all laws that have been duly enacted. Reading the presidential oath and the Take Care Clause together could lead in any of three directions. First, the President may have broad latitude to interpret the Constitution based on the belief that he has a duty to decline to enforce legislation he believes is unconstitutional. ${ }^{32}$ Second, the President may have the discretion to decline to enforce a statute he deems unconstitutional, but no obligation to do so. ${ }^{33}$ Third, the President may have a duty to enforce a duly enacted law notwithstanding his belief regarding the law's unconstitutionality. ${ }^{34}$ Which approach is appropriate in any particular situation depends on how aggressively the executive

29. U.S. CONST. art. II, § 1 .

30. See BRUFF, supra note 1 , at 1 ("The obvious purpose of the oath is to impose legal obligations."). But see MAY, supra note 5, at 38-41 (suggesting that the oath does not require a President to ignore laws that he believes to be unconstitutional).

31. U.S. CONST. art. II, $\S 3$.

32. Kelley, supra note 3, at 77 (explaining that since Watergate and Vietnam, Presidents have aggressively interpreted the oath and Take Care Clause to support executive power in the face of efforts by various institutions to limit the executive's powers).

33. Bradley \& Posner, supra note 11, at 335 ("Still other commentators argue for an intermediate position whereby Presidents may sometimes disregard statutes that they believe to be unconstitutional, such as when a statute violates a Supreme Court precedent or invades executive power.").

34. MAY, supra note 5, at 37 (discussing the framers' beliefs regarding a President's inability to nullify a law that he deems unconstitutional). 
branch decides to interpret the Constitution and whether the legislative and judicial branches cabin that aggressiveness.

\section{A. The Oath}

Presidential constitutional interpretation begins with the presidential oath of office. ${ }^{35}$ The President may not assume the office of President until he takes the oath. ${ }^{36}$ The oath requires that the President's actions be consistent with the Constitution, but the oath remains subject to interpretation. The oath requires that the President preserve, protect, and defend the Constitution, but not necessarily that the President preserve, protect, and defend the United States. ${ }^{37}$ Depending on how the President interprets the Constitution, actions that may be consistent with the document may harm the United States. For example, those who thought that secession was consistent with a compact theory of the Constitution would presumably have thought that the Confederate states were allowed to leave the Union. ${ }^{38}$ If voluntary entry and exit had been allowed under the Constitution, a President who believed that the Constitution allowed secession arguably should have let the Confederate states leave the Union even if that would have harmed the United States. ${ }^{39}$ Conversely, actions that

35. See U.S. ConsT. art. II, $\S 1, \mathrm{cl} .8$ ("Before he enter on the Execution of his Office, he shall take the following Oath or Affirmation:-'I do solemnly swear (or affirm) that I will faithfully execute the Office of President of the United States, and will to the best of my Ability, preserve, protect and defend the Constitution of the United States."').

36. Indeed, President Obama retook the oath of office after Chief Justice John Roberts had him recite a slightly incorrect oath at the inauguration. See Carolyn Lochhead, Obama Retakes Oath to Err on Side of Law, S.F. GATE, (Jan. 22, 2009, 4:00 AM), http://www.sfgate.com/politics/article/Obama-retakes-oath-to-err-onside-of-law-3253825.php [https://perma.cc/N6TL-KVK4].

37. See U.S. CONST. art. II, § 1.

38. See generally Edward A. Fallone, Charters, Compacts, and Tea Parties: The Decline and Resurrection of a Delegation View of the Constitution, 45 WAKE FOREST L. REV. 1067, 1092-93 (2010) (illustrating the compact theory of the Constitution); see also BRUFF, supra note 1, at 124 (discussing President Buchanan's beliefs that the states had no right to secede, but that the federal government could not use force to make them stay).

39. Adopting the United States Constitution functionally ended the Confederation created by the Articles of Confederation and arguably qualified as secession under the Articles of Confederation. See ARTICLES OF CONFEDERATION of 1781, art. XIII (noting that the Union created by the Articles of Confederation was to be perpetual). Leaving the Union and creating the Confederate States of America could be thought by some to be a replay of the adoption of the U.S. Constitution. 
violate the Constitution may protect the United States. For example, President Lincoln believed that the oath required that he preserve the Union and the Constitution. ${ }^{40}$ Consequently, he was willing to take action that appeared to contravene constitutional text to save the Union. ${ }^{41}$

The oath requires that the President be faithful to the Constitution. ${ }^{42}$ What that faithfulness entails may be for the President to determine. What faithfulness entails also depends on what other obligations the Constitution places on the President through text such as the Take Care Clause. The presidential oath, when combined with other constitutional obligations, may suggest that the President has significant latitude to interpret the Constitution.

\section{B. The Take Care Clause}

The President's duty to take care that the laws are faithfully executed is more specific than the presidential oath. How the duty is interpreted may structure the scope of the President's latitude to interpret the Constitution. The Take Care Clause can be read to require that the President interpret the Constitution and decline to enforce unconstitutional laws. Conversely, the Take Care Clause can be read to require merely that the President makes sure that executive branch officials faithfully execute duly enacted federal laws. ${ }^{43}$

The Constitution is the supreme law of the land. Any law-federal or state-that contravenes the Constitution is

40. See BRUFF, supra note 1 , at 127 (noting that Lincoln saw a Union where others saw "a confederation of sovereign states").

41. See Richard H. Fallon, Jr., Interpreting Presidential Powers, 63 DUKE L.J. 347,349 (2013) (noting that President Lincoln "concluded that the emergency rendered it constitutionally permissible for him to take steps that would almost surely have been legally impermissible in less extraordinary times"); see also BRUFF, supra note 1, at 132 (discussing President Lincoln's actions in 1861 that violated constitutional text, such as unilaterally raising an army and navy and spending money from the U.S. treasury without an appropriation, which were later ratified by Congress).

42. See U.S. CONST. art. II, § 1. Faithfulness is key. See Peter L. Strauss, The President and the Constitution, 65 CASE W. RES. L. REV. 1151, 1172-73 (2015) (suggesting that Presidents must consciously exercise a mindset permitting them to act as both servant to the Constitution and to the people).

43. See Bradley \& Posner, supra note 11, at 334 (noting that commentators are mixed regarding whether the President has a duty to enforce laws he thinks are unconstitutional). 
unconstitutional. ${ }^{44}$ The President's duty to take care that the laws are faithfully executed may obligate the President to decline to enforce unconstitutional laws. ${ }^{45}$ The argument rests on the notion that unconstitutional laws are void when passed. ${ }^{46}$ That would seem to require that the President interpret the Constitution to determine whether a duly enacted law could be enforced. As head of the executive branch, the President may also be obligated to make clear that executive branch officials cannot help execute unconstitutional laws. That obligation would lead to a very broad commission for the President to interpret the Constitution and to decline to enforce laws he believes are unconstitutional. ${ }^{47}$

Conversely, the President may have little latitude to interpret the Constitution based merely on the presidential oath and the Take Care Clause. Though the Constitution is the nation's highest law, ${ }^{48}$ federal statutes that have been passed pursuant to the Constitution also constitute the supreme law of the land. ${ }^{49}$ The President may have the responsibility to execute any statute that has been duly enacted under the Constitution's procedures-passage of both houses of Congress and presentment to the President-until that statute is declared unconstitutional. ${ }^{50}$ The thrust of the faithful execution

44. It has been so since the early days of the United States. See Marbury v. Madison, 5 U.S. (1 Cranch) 137, 180 (1803) ("Thus, the particular phraseology of the constitution of the United States confirms and strengthens the principle, supposed to be essential to all written constitutions, that a law repugnant to the constitution is void ....").

45. See COOPER, supra note 15, at 207 (discussing how the Take Care Clause may lead to signing statements that refuse to apply the law); see also Dellinger OLC Memo, supra note 10, at 133 (suggesting that presidential refusal to execute law based on President's interpretation of the Constitution is "consistent with the views of the Framers").

46. See Prakash, supra note 9, at 1649,1655 . However, an unconstitutional law may not be void $a b$ initio in all respects. See Chicot Cty. Drainage Dist. v. Baxter State Bank, 308 U.S. 371 (1940).

47. See Prakash, supra note 9, at 1617 ("[T]he President has a duty to disregard statutes he believes are unconstitutional.").

48. U.S. ConST. art. VI.

49. Id. art. VI. However, those laws must be consistent with the Constitution. See Marbury, 5 U.S. (1 Cranch) at 180 ("It is also not entirely unworthy of observation, that in declaring what shall be the supreme law of the land, the constitution itself is first mentioned; and not the laws of the United States generally, but those only which shall be made in pursuance of the constitution, have that rank.") (emphasis in original).

50. See MAY, supra note 5, at 38 (suggesting the President is obligated to enforce laws that he may think are unconstitutional). However, the duty may not be absolute. See Bradley \& Posner, supra note 11, at 336 (noting that some 
duty may be to command the President to ensure that the laws that Congress passes are executed by the executive branch rather than ignored. ${ }^{51}$ Whether the President believes that a particular law is unconstitutional may be irrelevant to the duty to faithfully execute federal law. ${ }^{52}$

\section{Clearly Unconstitutional Laws}

If the President has no latitude to interpret the Constitution and to decline to enforce unconstitutional laws, a President may be forced to execute a law that he believes is unconstitutional. That is not necessarily a problem when the constitutionality of the law at issue is debatable and the President could be wrong about his interpretation. In that instance, a refusal to exercise the law would trigger a violation of the faithful execution duty. When the constitutionality of a law is not clear, the President arguably should assume that the statute is constitutional. ${ }^{53}$ However, if the President is correct about the law's unconstitutionality, executing such a law could lead to an extended period of enforcement of an unconstitutional law. ${ }^{54}$ If the presidential oath is akin to an on/ off switch that triggers the obligation to enforce constitutional laws and the obligation to decline to enforce unconstitutional laws, it is unclear that the oath would condone a practice that would require that the President enforce a law that he believes is unconstitutional.

Supreme Court "decisions and statements could be read as providing modest support for a Presidential power to disregard at least some unconstitutional statutes").

51. President Nixon's position on impoundment-that he could decline to spend money that had already been appropriated for a particular purposetriggers the notion that a President may have to be made to enforce federal law. See BRUFF, supra note 1, at 342-46 (discussing President Nixon and impoundment); Henry L. Chambers, Jr. \& Dennis E. Logue, Jr., Separation of Powers and the 1995-1996 Budget Impasse, 16 ST. LOUIS U. PUB. L. REV. 51, 5859 (1996) (discussing same).

52. The President's inability to stop the enactment of a law with a vetoCongress can override a presidential veto-may suggest that the President should not be able to refuse to enforce a law merely because he believes it to be unconstitutional. See infra Section II.B.

53. See SHANE, supra note 2, at 133 (noting that the President may avoid vetoing a bill when its constitutionality is in question and leave the close constitutional calls to the courts).

54. Courts sometimes do not decide the constitutionality of a law until well after it is passed. See generally Dickerson v. United States, 530 U.S. 428 (2000) (deciding constitutionality of statute passed in 1968). 
Requiring the President to enforce a law the President believes to be unconstitutional is even more problematic if the law at issue appears to be clearly unconstitutional. By enforcing such a law, the President would appear to violate his oath of office by adhering to a narrow interpretation of the Take Care Clause. However, any requirement that the President enforce a law that appears clearly unconstitutional may be a feature of the constitutional order rather than a bug. The President can work within the constitutional system to attempt to procure a determination of constitutionality before acting on his independent interpretation. ${ }^{55}$ This may not always be practical or possible given that the Supreme Court does not issue advisory opinions and may only render judgment in a live case or controversy. .56

The President can simply assert a duty to decline to enforce a clearly unconstitutional law and refuse to enforce the law. That solution is impossible to administer given that whether a law ought to be deemed clearly unconstitutional depends on who is interpreting the statute and the Constitution. Just as importantly, there may be little that would limit the duty. Over time, the duty would almost certainly expand to provide the President with a fairly broad capacity to exercise presidential prerogative. Even without an explicit duty to interpret the Constitution, Presidents have deemed their latitude to interpret the Constitution to be broad. ${ }^{57}$ Those interpretations of presidential latitude have arguably become a part of constitutional law..$^{58}$ Allowing such interpretations to stand functionally changes the scope of the President's latitude to interpret the Constitution based on a presidential interpretation of the presidential oath and the Take Care Clause. ${ }^{59}$ Nonetheless, that assumed latitude is

55. See MAY, supra note 5, at 119 (suggesting that there are multiple ways for a President to address a law he believes unconstitutional without declining to enforce it).

56. See U.S. CONST. art. III, $§ 2$ (limiting jurisdiction of federal courts to cases or controversies).

57. See, e.g., BRUFF, supra note 1, at 95-99 (discussing President Andrew Jackson and the Second Bank of the United States imbroglio).

58. Bradley \& Morrison, supra note 20, at 1098 (noting the role historical practice plays in defining executive authority).

59. References to the presidential oath and past practice may become trump cards in any discussion of the proper scope of the President's ability to interpret the Constitution and act on that interpretation. See PFIFFNER, supra note 4, at 223 (suggesting that the Reagan administration "strategically" sought to make 
crystallized and operationalized in signing statements.

\section{Constitu'tional Signing STAtements and Vetoes}

Constitutional signing statements explain how the President will execute a law or why he will decline to execute the law, consistent with her understanding of the Constitution. They can be considered acts of candor or acts of defiance. 60 When a President declines to enforce legislation he believes unconstitutional, he may be thought to be either a usurper of power or a coequal constitutional actor reasonably interpreting the Constitution. How the President and the signing statement are characterized may depend on how closely the argument underlying the signing statement conforms to standard constitutional analysis and also may depend on whether the veto should be deemed the President's sole tool for expressing her belief that legislation is unconstitutional. ${ }^{61}$

\section{A. Refusal to Enforce Law}

A constitutional signing statement that threatens a refusal to execute a law can be based on the belief that a provision of the law is unconstitutional no matter how the law is interpreted. Alternatively, it can be based on the belief that the provision could be interpreted either in a constitutional manner or in an unconstitutional manner, with the signing

signing statements a part of the legal landscape, "so as in the future to be able to claim that the signing statements establish precedents that are part of the record of constitutional interpretation"); Fallon, supra note 41, at 364 ("[P]revious administrations have cited executive precedent to justify assertions of unilateral executive authority to do nearly anything that the President has deemed desirable in the name of national security, up to and including the initiation of war in every practical sense of the term.").

60. See Bradley \& Morrison, supra note 20, at 1114 (distinguishing noncompliance with the law and genuine disagreement regarding what the law requires). A signing statement can be an act of defiance when it provides little explanation for its issuance. See SHANE, supra note 2, at 135 (noting that many of President George W. Bush's signing statements were "based on no legal authority whatever and had nothing to do with any plausible version of the public interest"); Kelley, supra note 3, at 73.

61. Some argue that the ideology embedded in the signing statement, rather than the practice of issuing signing statements, is the real issue. See Bradley \& Posner, supra note 11, at 310 ("All of this [criticism of signing statements] suggests that the real concern is not with the institution of signing statements but with the Bush administration's underlying views of executive power."). 
statement making clear that the provision will only be executed in a manner the President believes to be constitutional. The latter position is sensible unless it is clear that the President has interpreted the legislation in a manner clearly contrary to Congress's intent in order to claim to be enforcing the law while actually declining to do so. ${ }^{62}$ In that circumstance, the President's position is functionally similar to a claim that the legislation is unconstitutional however interpreted.

A signing statement does not necessarily challenge congressional authority. ${ }^{63}$ Rather, it can be considered a necessary manifestation of executive power. The President retains constitutional control over the executive branch and must direct executive branch officials on how to enforce the law. ${ }^{64} \mathrm{~A}$ signing statement guides executive branch officials in enforcing or declining to enforce the law. ${ }^{65} \mathrm{~A}$ constitutional signing statement may be most appropriate when legislation concerns an issue on which the President has primary authority, thereby infringing executive power and upsetting the system of separation of powers embedded in the Constitution. ${ }^{66}$

62. Some Presidents appear to have intentionally misinterpreted the law. See COOPER, supra note 15, at 208 (noting the practice of "interpreting provisions that were clearly intended to be mandatory as advisory only"); Bradley \& Posner, supra note 11, at 342 (" $[\mathrm{I}] \mathrm{t}$ is useful to distinguish between situations in which a statute is truly ambiguous, and situations in which the President is purporting to interpret a statute when in fact his interpretation is contrary to its plain meaning.").

63. They can also be bald attempts to increase power. See SHANE, supra note 2 , at 141 ("What happened from 2001 to 2006 was Bush Administration exploitation of congressional passivity to generate a series of documentary artifacts that can impersonate as legal authority for unilateral Presidentialist legal interpretation.").

64. See id. at 138-39 (discussing signing statements that object to Congress telling executive branch officials to do something because it conflicts with the President's right to tell executive branch officials what to do as unitary executive). However, the President's belief that he alone can direct executive branch officials may not be as strong as some suggest. See PFIFFNER, supra note 4, at 219-22 (discussing unitary executive theory and suggesting that the claim that only the President can give orders to executive branch officials is not convincing based on arguments extant at the framing of the Constitution).

65. See PFIFFNER, supra note 4, at 207 (noting that the Dellinger OLC memo suggests that signing statements can be used to direct the actions of executive officials).

66. See Dellinger OLC Memo, supra note 10, at 134 ("If so, then a signing statement that challenges what the President determines to be an unconstitutional encroachment on his power, or that announces the President's unwillingness to enforce (or willingness to litigate) such a provision, can be a valid 
However, under certain circumstances, a signing statement is an act of defiance. When a signing statement merely contains a general assertion that the law at issue infringes on the President's executive power and will be interpreted in a manner consistent with a broad vision of executive power, it appears to be an act that intentionally disrespects legislative authority. ${ }^{67}$ The latter approach was arguably taken by President George W. Bush's administration and may have triggered some of the concern about signing statements during his presidency. ${ }^{68}$

Presidents who issue constitutional signing statements presumably believe they have a duty or a right to decline to enforce unconstitutional laws. ${ }^{69}$ If they are correct, a constitutional signing statement is a legitimate exercise of power, even if the President's constitutional interpretation is ultimately rejected. ${ }^{70}$ Conversely, if the President's duty is to execute the law, not to decide whether to execute the law, signing statements are generally suspect and may be considered a usurpation of legislative power even if the President's opinion on the law's constitutionality is ultimately deemed correct. ${ }^{71}$ As the President is the only constitutional

and reasonable exercise of Presidential authority."); see also Prakash, supra note 9, at 1624 ("One might suppose that the President may disregard statutes only when he believes that they unconstitutionally infringe upon his constitutional powers. For instance, if a statute forbids the President from vetoing legislation, he may nonetheless issue vetoes if he believes that the veto prohibition is unconstitutional.").

67. See Kelley, supra note 3, at 73 (noting President George W. Bush's assertion that he would generally construe law to comport with his powers under the unitary executive doctrine).

68. See PFIFFNER, supra note 4, at 194-96 (arguing that the breadth of the justifications that President Bush asserted to underlie his signing statements challenged the Constitution's separation of powers regime).

69. See Dellinger OLC Memo, supra note 10, at 133 ("In each of the last three Administrations, the Department of Justice has advised the President that the Constitution provides him with the authority to decline to enforce a clearly unconstitutional law."); COOPER, supra note 15, at 206-07 ("The Office of Legal Counsel under the Reagan, Bush, and Clinton administrations argued that the President has the power to refuse to enforce a statute if he or she determines that the statute violates the Constitution."); Kelley, supra note 3, at 84 (noting that Walter Dellinger's Office of Legal Counsel memorandum on signing statements, Dellinger OLC Memo, supra note 10, suggested that they are consistent with the President's obligations under the Take Care Clause and the presidential oath).

70. However, if signing statements are meant merely to expand executive power, there is a problem. See COOPER, supra note 15, at 202 (noting use of signing statements as an attempt to expand executive branch authority).

71. See PFIFFNER, supra note 4, at 196-97 (likening signing statements to the 
actor charged with executing federal law, a refusal to execute a law functionally negates Congress's legislative power. ${ }^{72}$ Even if the President may rightly consider the constitutionality of a law before executing it, he has other avenues for voicing his concern regarding the unconstitutionality of legislation that may make issuing a constitutional signing statement improper. ${ }^{73}$

\section{B. The Veto}

If a constitutional signing statement essentially negates legislative power, the President's issuance of such a statement can be considered particularly problematic because the President already has a role in the legislative process. The President may veto legislation. ${ }^{74}$ The President's veto power affords him an opportunity to voice constitutional concerns during the legislative process. ${ }^{75}$ The President can and arguably should veto bills he believes contain unconstitutional provisions. ${ }^{76} \mathrm{~A}$ veto is not necessary if the President merely objects to a particular interpretation of a statutory provision rather than to the entire provision. ${ }^{77}$ The veto is not absolute, but it allows the President to slow legislation he believes unconstitutional. ${ }^{78}$

monarchical power to suspend the laws, which was explicitly not given to the President).

72. See U.S. CONST. art. I.

73. See PFIFFNER, supra note 4, at 227 (noting that there are other ways to address and resolve constitutional interpretation questions than allowing the President to assert what the law is).

74. U.S. CoNST. art. I, $\S 7$. Some suggest that the veto may be the sole appropriate action the President can take in this circumstance. See MAY, supra note 5, at 38 (suggesting the founders believed the President should veto a law or go to court to have it declared unconstitutional); PFIFFNER, supra note 4, at 214 ("That the designers of our Constitution gave the executive a qualified veto is a strong argument that they did not intend that the President have the authority not to carry out the law.").

75. See Jackson, supra note 5 , at 4 ("The power to veto a bill, although exercised by the executive branch, is legislative in nature.").

76. See SHANE, supra note 2, at 133 (suggesting that the President should veto unconstitutional bills, but that good reasons for declining to do so exist).

77. At times, vetoing an entire bill is not feasible. See CoOPER, supra note 15, at 211 (noting the argument that when vetoing a huge bill is not practical, issuing a signing statement has been used by Presidents to address the issue of smaller unconstitutional portions of law).

78. See U.S. ConST. art. $1, \S 7$ (providing that a veto may be overridden if two-thirds of each house of Congress repasses the legislation). 
A veto can yield three possible results. First, Congress may pass a new bill without the offending provision. That is preferred from the President's perspective, but is unlikely. Congress and the President may discuss legislation while it is being crafted. If the President made clear that a provision in the original bill would trigger a veto, but Congress left the provision in the bill, it is unlikely that Congress would pass a second bill post-veto without the offending provision. This is so particularly if Congress believes the offending provision to be constitutional and beneficial. There may be other political reasons why Congress might pass the bill the President prefers after the veto, but it is unclear that a constitutional objection would likely lead to such a result.

Second, in response to the veto, Congress could decline to pass any substitute legislation. If so, the President has foregone all of the possible benefits that would have accompanied the original bill. This might result from the President and Congress standing on principle, but is not necessarily best for the country. However, if the country lost good legislation because Congress wanted a provision in the law that the President reasonably believed was unconstitutional, the loss may be Congress's responsibility rather than the President's.

Third, in response to the veto, Congress could override the veto and keep the offending provision in the law. Presumably, the President would still issue a signing statement, as the override would not necessarily make the provision any less unconstitutional from the President's perspective, and refuse to execute the law. ${ }^{79}$ That is roughly the same position the legislation would have been in had the President issued a signing statement when the legislation was first passed. Rather than going through a veto override process, signing the legislation while flagging the constitutional issue in a signing statement and leaving its ultimate resolution to the Supreme Court may be the preferred outcome under a constitutional order that deems the Supreme Court the ultimate arbiter of constitutionality. This does not convert signing statements into

79. However, that approach may be of recent vintage. See MAY, supra note 5, at 69 (noting that through 1981, Presidents almost uniformly implemented statutes that they believed were unconstitutional when such statutes were passed over the President's veto, even when it was very unlikely that other litigants would be able to challenge the statute in court). 
line-item vetoes. ${ }^{80} \mathrm{~A}$ law subject to a signing statement has not been repealed and may yet be executed if the President changes his mind regarding its constitutionality or if the Supreme Court deems the law or the President's interpretation of the law to be constitutional. ${ }^{81}$

\section{Implications}

Relying on the veto power alone to signal concerns with the constitutionality of legislation may not be an adequate solution. 82 The veto is a reasonable way, and a threatened veto may be the best way, to voice concerns regarding the constitutionality of legislation. ${ }^{83}$ However, if the veto is ineffective, a President with an aggressive view of the Take Care Clause may believe he must decline to execute the statute. ${ }^{84}$ A signing statement honestly announces that intention. The President could sign a bill into law without a signing statement, then decline to enforce the part of the law to which he objects. ${ }^{85}$ The President may pay a political price for issuing an honest signing statement, but the political price arguably should come from being wrong about whether the law is unconstitutional rather than from acting on the belief that

80. Some argue that a signing statement can act as a line-item veto. See, e.g., COOPER, supra note 15 , at $223-25$ (treating signing statement as line-item veto that is just as problematic to the legislative process as the unconstitutional legislative veto was); MAY, supra note 5 , at 72 (suggesting that signing statement is the equivalent of line-item veto when "the constitutional objection is coupled with a Presidential refusal to comply with the law"); PFIFFNER, supra note 4, at 202.

81. See Prakash, supra note 9, at 1622 (noting that a law that has been deemed unconstitutional is not stricken from statute books and can be enforced if the President wishes).

82. See id. at 1619 (suggesting that the fact of veto power does not alter the President's duty to decline to enforce unconstitutional laws).

83. See Jackson, supra note 5, at 5 (suggesting that the threat of a veto may encourage Congress to make changes to a bill that will make the legislation palatable to the President).

84. See Prakash, supra note 9, at 1616-17 (arguing that the oath and Take Care Clause require that the President disregard statutes he believes are unconstitutional).

85. A President could decline to enforce the law through a form of prosecutorial discretion. This is arguably occurring with respect to enforcing or declining to enforce some federal marijuana laws. See U.S. DEP'T OF JUSTICE, OFFICE OF THE DEPUTY ATTORNEY GEN., MEMORANDUM FOR ALL UNITED STATES ATTORNEYS: GUIDANCE REGARDING MARIJUANA ENFORCEMENT 1-2 (2013), http://www.justice.gov/iso/opa/resources/3052013829132756857467.pdf [https:// perma.cc/XHQ6-KQ73]. 
the law is unconstitutional. ${ }^{86}$ Whether the President is deemed wrong about her opinion on constitutionality may depend on how closely the President's interpretation tracks the Constitution's text. A constitutional signing statement with a clear textual basis may be less likely to be politically unpalatable than one with little textual basis. However, whether constitutional signing statements are appropriate depends, in part, on two issues to be discussed below: (1) whether the Constitution should be treated as a legal document or political document, and (2) whether presidential constitutional interpretation should be cabined by congressional and Supreme Court constitutional interpretation.

\section{INTERPRETING THE CONSTITUTION AS A LEGAL DOCUMENT OR AS A POLITICAL DOCUMENT}

The President must interpret the Constitution in the course of his constitutional duties. How the President determines what laws he deems unconstitutional may depend on whether the Constitution is treated as a legal document or as a political document, and whether unconstitutionality is defined as inconsistency with the Constitution's text or inconsistency with the Constitution's principles. The Constitution can be interpreted as a legal document that is informed by the political principles embedded in it. ${ }^{87}$ Conversely, it can be interpreted as a political document that includes legally enforceable rules. Those two visions of the Constitution may converge when constitutional actors consider a concrete issue. However, an approach that views the Constitution as primarily a legal document will tend to seek a legal solution; an approach that views the Constitution as a political document will tend to seek a political solution. How the Constitution should be characterized depends, in part, on how one interprets its somewhat unclear and malleable text. ${ }^{88}$

86. See Prakash, supra note 9, at 1639 (suggesting impeachment for a particularly bad exercise of refusal to execute law the President believes is unconstitutional).

87. See Henry L. Chambers, Jr., Biblical Interpretation, Constitutional Interpretation, and Ignoring Text, 69 MD. L. REV. 92, 93 n.5 (2009) ("Justice Breyer does not exalt any particular canon of interpretation. Rather, he suggests that one should consider the Constitution's overarching theme-active liberty-to interpret the Constitution's text.").

88. It can be interpreted based on principles or more closely based on text. See 
If the gaps created by the Constitution's imprecise language are filled principally through legal analysis and interpretation, the Constitution may be treated as a legal document that ought to be interpreted primarily or solely by courts. If those gaps are filled principally through reference to the political principles that undergird the Constitution, the Constitution can be treated primarily as a political document that can be interpreted through a principled political lens by the President and Congress. The Constitution's meaning would be determined by the political branches or more generally by the political process.

The appropriate scope of the President's latitude to interpret the Constitution and to act on that interpretation may be significantly affected by which of these two visions the President and other constitutional actors adopt. That may depend on how the Constitution has been interpreted in practice through the iterative processes that can settle the text's meaning. ${ }^{89}$ Whether the Constitution is considered a legal document or a political document can affect how the President defines unconstitutionality. If the Constitution is treated as a legal document, a President arguably should deem a statute unconstitutional only if it is inconsistent with the Constitution's text. Conversely, if the Constitution is treated as a political document, a statute may be unconstitutional if it violates the principles underlying the Constitution.

\section{A. Constitution as a Legal Document}

The Constitution may be considered a legal document that has political principles embedded in its text..$^{90}$ It is the supreme law of the land. ${ }^{91}$ Ratified as law by the states as sovereigns

id. at 92 n. 1 (noting that Supreme Court justices have taken different positions on the role of text and the role of overarching principles in constitutional interpretation).

89. See BRUFF, supra note 1 , at 457-58 (describing an iterative process whereby the Constitution's meaning can become fixed).

90. See GARRETT EPPS, AMERICAN EPIC: READING THE CONSTITUTION, at xvi (2013) "And the second way you and I can read the Constitution is in fact as a set of rules written to operate as law, to be read as law using the methods lawyers use."); Gary Lawson \& Guy Seidman, Originalism as a Legal Enterprise, 23 CONST. COMMENT. 47, 51 (2006) ("The Constitution is a legal document. It should not be surprising that a legal document is best construed through legal means.").

91. See U.S. ConsT. art VI. 
through state ratifying conventions, ${ }^{92}$ the Constitution appears to be a legal agreement that became the binding governing legal document of the Union once nine states agreed to it.93 Given that the Constitution was ordained to help create a more perfect union, it can be considered a strict, legally binding plan for fostering that result. ${ }^{94}$ The Constitution may be considered the rulebook that creates a government that We the People hoped would foster the preamble's goals. ${ }^{95}$

However, the Constitution is not a typical legal document. ${ }^{96}$ It does not read like a typical legal document. ${ }^{97}$ Though the Constitution contains some clear rules, ${ }^{98}$ the Constitution's text is not as clear as might be expected of an enforceable legal document. ${ }^{99}$ In addition, its aim is not necessarily to enforce its rules against signatories, as if a treaty or contract, but rather to create a well-functioning Union. ${ }^{100}$ Given that states surrendered much, if not all, of their sovereignty by joining the Union, the states arguably should not treat the document as a contract between statesthough states may exercise rights against each other-but rather as a set of rules that applies to the federal government,

92. Id. art. VII.

93. Id.

94. See id. pmbl. It can be considered a blueprint for government. See Lawson \& Seidman, supra note 90 , at 52.

95. See Henry L. Chambers, Jr., Book Review, Holy Writ: Interpretation in Law and Religion, 26 J.L. \& RELIGION 635, 636 (2011) (noting that Justice Scalia has described the Constitution as "a legal document that provides legally enforceable rights").

96. See Caleb Nelson, Originalism and Interpretive Conventions, 70 U. CHI. L. REV. 519, 569 (2003) ("Because different types of legal documents triggered different rules of construction, early interpreters of the Constitution had to decide which set (or sets) of rules it implicated. This question, however, did not necessarily have a determinate answer. The Constitution was a novel type of legal document; it was not exactly like a statute, or a treaty, or a contract, or indeed anything that lawyers had previously had to interpret.")

97. See EPPS, supra note 90, at xxi (considering reading the Constitution as law, but also as a non-legal text).

98. See, e.g., U.S. CONST, art. I, $\S 3$ (noting that each state shall have two senators who serve six-year terms and have one vote).

99. See SHANE, supra note 2, at 113 ("[T]he Constitution, the document that vests the President with whatever core powers he has, is notoriously vague.").

100. Even if the Constitution is to be treated as a strictly legal document, it is not clear what type of legal document it is supposed to be and how that might affect its interpretation. See Nelson, supra note 96, at 522 ("Among other difficulties, founding-era interpretive conventions differed for different types of legal documents, and it was not clear whether the Constitution should be interpreted like a treaty, a statute, a contract, or something else."). 
the Union, and its citizenry. ${ }^{101}$

\section{B. The Constitution as a Political Document}

The Constitution may be treated as a political document that contains legally enforceable rules. ${ }^{102}$ It creates a governing structure for the United States and expounds a set of principles for administering the country and for fostering a more perfect union. It may serve as a guidebook that provides certain bedrock principles, but which affords room for future generations to create the republic each generation needs in order to foster the preamble's goals. ${ }^{103}$ Though the Constitution contains some rules that must be adhered to as law, the document's underlying political principles may exist to guide the interpretation of the legally enforceable rules embedded in its text. ${ }^{104}$

The Constitution's purpose was political; political principles are embedded in the document. ${ }^{105}$ The politics began with the preamble's reference to "We The People of the United States." 106 The Declaration of Independence and the Articles of Confederation made clear that the United States of America

101. See U.S. CoNST. art. III, $\S 2$ (contemplating cases or controversies between states that the federal courts may be required to resolve).

102. Arguably, the Constitution can be read as a continuation of the Declaration of Independence. See Lee J. Strang, Originalism, the Declaration of Independence, and the Constitution: A Unique Role in Constitutional Interpretation?, 111 PENN. ST. L. REV. 413, 413 (2006) ("The role of the Declaration of Independence in constitutional interpretation is contested. Some argue that it is 'at the heart of the Constitution,' that the Declaration 'is fundamental to a proper understanding of the Constitution,' and that Americans should interpret 'the Constitution through the lens of the Declaration.") (citations omitted).

103. See JACK M. BALKIN, LIVING CONSTITUTIONALISM 11 (2011) ("In every generation, We the People of the United States make the Constitution our own by calling upon its text and its principles and arguing about what they mean in our own time.").

104. See EPPS, supra note 90, at xii ("[The Constitution's] text offers us at the most basic level the means we can employ today to create a 'more perfect union ... to ourselves and our posterity'; at a deeper level, it tells us much about who we are and how we got here. It is a tool kit of our politics and a testament of our history.").

105. For example, the Court recently located an equal sovereignty doctrine embedded in the Constitution. See Shelby Cty. v. Holder, 133 S. Ct. 2612, 2623 (2013) (divining equal sovereignty principle gleaned from the structure of the Constitution).

106. U.S. CONST. pmbl. 
was then a confederation of independent states. ${ }^{107}$ The preamble's reference to "We The People" as establishing the Union, rather than to the states creating the Union-as was the case with the Articles of Confederation-suggested that the Constitution formed a nation rather than merely a new and somewhat stronger confederation than had existed under the Articles of Confederation. ${ }^{108}$ The strength of the union matters, as the obligations states owe to a nation and that the nation may owe to states may be different than the obligations owed by and to a confederation. ${ }^{109}$ Similarly, the obligations owed to citizens or people subject to a nation may be different than the obligations owed to citizens of states that have joined a confederation. All of these issues and principles may be relevant to how the constitutional text should be interpreted. ${ }^{110}$

Though constitutional text can usually be read to create legal rights and obligations, the point of the text can be quite political.111 The Constitution contains fundamental, but undefined, phrases, such as "executive power," "the equal protection of the laws," and "privileges and immunities."112 It also includes fundamental notions-such as the existence of undefined unenumerated rights and powers - that are not

107. The Declaration noted that states had rights consistent with their free and independent status. See DECLARATION OF INDEPENDENCE ("[T] hey have full power to levy war, conclude peace, contract alliances, establish commerce and do all other acts and things which independent states may of right do."). The Articles noted the same. See ARTICLES OF CONFEDERATION of 1781, art. II ("Each state retains its sovereignty, freedom and independence[.]").

108. See ARTICLES OF CONFEDERATION of 1781, art. III (deeming the Articles to create "a firm league of friendship").

109. For example, the constitution guarantees that each state will have a republican government. U.S. CONST. art. IV, $\S 4$. That guarantee makes more sense in a nation than in a confederation.

110. See Chambers, supra note 87 , at 113 ("If the Constitution is literally just a mass of words that creates a government and governs those subject to it based on its commands, so be it. If, however, it is supposed to provide a way or vision of living, it should be made as consistent as possible with the way of living it embodies.").

111. For example, Article I gives Congress the legal right to "be the Judge of the Elections, Returns and Qualifications of its own Members." U.S. CONST. art I, $\S 5$, cl. 1. However, the implication of the text is that each House is to be given some latitude to govern itself and its members, though that freedom is nowhere near complete. See Powell v. McCormack, 395 U.S. 486 (1969) (limiting Congress to judging the qualifications of its members, rather than giving Congress the discretion to seat or not seat whomever Congress wishes).

112. See SHANE, supra note 2, at 114 ("[T]he Constitution is ambiguous, at best, on the nature of executive power."). 
explained in the Constitution's text. ${ }^{113}$ Those phrases and notions can be given legal meaning, but may have as much salience as political principles.

Further, the Supreme Court's political question doctrine suggests that some constitutional issues are to be solved by politics or through the political process rather than by law. ${ }^{114}$ For example, the Senate's advice and consent power is exercised in conjunction with the President's nominating power. ${ }^{115}$ That suggests that the President and the Senate may disagree regarding Supreme Court nominees, but must come to an agreement before a nominee is confirmed. However, the document does not discuss how the President and the Senate will resolve a disagreement regarding a nominee or address a Senate's refusal to hold hearings or vote on a nomination. Without any legal principle to resolve the issue, the political process appears to be the Constitution's preferred (or only) method of resolution. ${ }^{116}$ Conversely, the Constitution provides a specific mechanism for resolving certain other legislative disputes. The President may veto legislation, but the legislation becomes law if two-thirds of the Senate and of the House of Representatives vote to override the veto. ${ }^{117}$ The President and Congress may disagree regarding the substance of the legislation, but the legislation is law once the veto is overridden. The Constitution's clear rules coupled with the existence of federal courts to declare the legislation to be law may suggest that the Constitution's clear rules are legally enforceable rules that accompany a political document's statement of principles.

113. See U.S. CONST. amends. IX, X.

114. See Zivotofsky v. Clinton, 132 S. Ct. 1421, 1427 (2012) (noting that the political question doctrine precludes courts from deciding issues that the Constitution gives to a coordinate branch to solve).

115. The President nominates, but the Senate must "advise and consent" to the nomination before an appointment can be made. U.S. CONST. art. II, § 2 , cl. 2 .

116. See Nelson, supra note 96, at 597 ("The modern political-question doctrine effectively takes this position; one of its functions is to distinguish between indeterminacies that the courts will address and indeterminacies whose liquidation they will leave to others. The Supreme Court has identified a few indeterminacies whose resolution the Constitution itself implicitly commits to nonjudicial actors.").

117. U.S. CONST. art. I, $\S 7, \mathrm{cl} .2$. 


\section{Filling the Constitution's Interstices}

Some of the Constitution's text is clear; some is unclear. Clear text must be treated as easily interpreted binding law. ${ }^{118}$ For example, a thirty-three-year-old cannot be President given the requirement that the President be at least thirty-five years old. ${ }^{119}$ In addition, a state cannot be denied the votes of its senators without its consent. ${ }^{20}$ However, the Constitution contains pockets of uncertainty. That uncertainty is created by unclear text or by a dearth of text, and can create interstices in the document that must be filled. How the gaps are filled is important. They can be filled through legal analysis or through political analysis or a combination of both. Legal analysis may require that the interpreter consider the remainder of the document to determine what the text at issue means. If a meaning cannot be found, the text may have to be considered silent on the issue or ambiguous, and possibly impossible to apply. ${ }^{121}$ Conversely, when text is interpreted based on the political principles underlying the document, the meaning of ambiguous text can become the meaning of the text that is most consistent with those principles, even if that reading may not appear to be the most natural reading of the text. The nature of the document may depend on how those uncertain interstices are filled or have been filled with meaning. If those gaps are filled primarily through textual and legal analysis, the Constitution functionally becomes a legal document with embedded political principles. Conversely, if those interstices are filled primarily based on the political principles that undergird the Constitution, the Constitution functionally becomes a political document that contains legally enforceable rules. The interstices are filled over time by presidential and congressional action and inaction and by judicial decisions. ${ }^{122}$

118. See Chambers, supra note 87 , at $112-13$ (noting that no amount of interpretation can change the meaning of clear text, though the text may need to be ignored at times).

119. U.S. CONST. art II, § 1, cl. 4.

120. Id. art. V.

121. Chambers, supra note 95, at 636 (noting that Justice Scalia has suggested that courts should interpret the Constitution sparely so as not to invade the legislature's province).

122. Indeed, some of the actions that can create constitutional meaning are unreviewed or unreviewable by the courts. See EPPS, supra note 90, at xi ("[M]any important parts of the Constitution are never tested in any court. The other two branches of government make decisions all the time, and not all of them can give 
Even when constitutional text or its implications appear clear, operationalizing the text can be difficult. For example, the Fourteenth Amendment's Equal Protection Clause has been interpreted to require that a state's laws apply equally to all people under the state's jurisdiction. ${ }^{123}$ However, because legislation often differentiates one group from another, courts created tiers of scrutiny-rational basis, intermediate scrutiny, and strict scrutiny-to help operationalize the Equal Protection Clause and evaluate state action. ${ }^{124}$ Tiers of scrutiny may be sensible given how the Constitution's equality principles mesh with real legislation, but tiers of scrutiny are not required by the Constitution's text.

Much of the Constitution's text is unclear. ${ }^{125}$ Unclear text can be interpreted as legally binding text or politically salient principle. For example, the President is removed from office if he is impeached by the House of Representatives and convicted by the Senate of committing high crimes and misdemeanors. ${ }^{126}$ If the Constitution is treated as legally binding text, determining precisely what offenses or what style of offenses constitute high crimes or misdemeanors ought to be critical in an impeachment trial. Unless the offense at issue is defined as a high crime or misdemeanor, the President ought not be removed from office.

Interpreting a political document may trigger a different analysis. The House of Representatives impeaches; ${ }^{127}$ the Senate tries all impeachments. ${ }^{128}$ There are few rules in the Constitution regarding the impeachment trial for the President other than that the Chief Justice of the United States must preside at trial and that two-thirds of senators must vote to

rise to a lawsuit."). Indeed, almost any hint of supposed authority can support governmental action. See SHANE, supra note 2, at 112-13 (noting that Presidents may be comfortable with their actions and Americans may believe we still have a government of laws as long as some authority for Presidential acts exists, be it "a constitutional provision, a statute, a judicial opinion, or an executive branch regulation").

123. See Henry L. Chambers, Jr., Retooling the Intent Requirement Under the Fourteenth Amendment, 13 TEMP. POL. \& C.R. L. REV. 611, 611-13 (2004) (discussing the Equal Protection Clause).

124. For discussion of equal protection and tiers of scrutiny, see City of Cleburne v. Cleburne Living Ctr., 473 U.S. 432, 440-41 (1985).

125. See Nelson, supra note 96 , at 538 (noting that parts of the Constitution are clear and parts are ambiguous).

126. U.S. CONST. art. II, $\S 4$.

127. Id. art. I., § 2, cl. 5 .

128. Id. art. I, $\S 3$, cl. 6 . 
convict. ${ }^{129}$ Consequently, the political principles that underlie the Constitution may suggest that high crimes or misdemeanors encompass any behavior that two-thirds of the Senate believes is serious enough to warrant conviction and removal of the President. ${ }^{130}$ Neither the legal nor the political approach to determining what constitutes a high crime or misdemeanor is necessarily correct or incorrect. They are different approaches to the same constitutional issue.

\section{Constitutionality and Unconstitutionality}

How unconstitutionality is defined may depend on the nature of the Constitution. Unconstitutionality can have at least two meanings. It may be narrowly construed to apply to only those actions that violate constitutional text or it may be more broadly construed to apply to any actions that violate the principles underlying the Constitution. ${ }^{131}$ Those approaches to unconstitutionality may not differ much in practice, but they describe different mindsets. A text-bound view of unconstitutionality will tend to yield fewer unconstitutional actions than a broader principles-based view of unconstitutionality. A broader vision of unconstitutionality provides more latitude to the President to declare laws unconstitutional and decline to enforce legislation as a result.

Unconstitutional legislation can come in three different forms. First, legislation can violate constitutional text and the principles underlying the Constitution. The Sedition Act, passed in the early days of the Republic to combat supposed seditious libel against the government, may qualify. It arguably violated the text of the First Amendment through its ban on certain forms of political expression. ${ }^{132}$ In addition, the political motivation of the Sedition Act may have violated the

129. Id.

130. See EPPS, supra note 90, at xi (noting disagreement about whether the actions for which President Clinton was impeached amounted to high crimes and misdemeanors).

131. Compare Obergefell v. Hodges, 135 S. Ct. 2584, 2597-606 (2015) (finding limitations on same-sex marriage unconstitutional based on liberty principles embedded in the Constitution), with id. at 2611-12 (Roberts, J., dissenting) (suggesting that the Constitution's text does not limit how states can regulate or deny same-sex marriage), and id. at 2627-28 (Scalia, J., dissenting) (same).

132. For a discussion of President Jefferson and his handling of the Sedition Act, see BRUFF, supra note 1, at 63-65; Prakash, supra note 9, at 1664-67. 
spirit of the First Amendment. 133

Second, a statute may violate the spirit of the Constitution, but not its text. The Tenure of Office Act-the post-Civil War statute aimed at limiting how President Andrew Johnson could dismiss executive branch officials-may be an example. ${ }^{134}$ There is no constitutional text that stops Congress from limiting the President from firing one of his cabinet secretaries. However, if one believes that the Constitution encompasses a principle that allows the President to control executive branch officials, possibly through a strong view of the executive power vesting clause, the Tenure of Office Act's limitation on when and how the President could dismiss a cabinet secretary would likely appear unconstitutional. ${ }^{135}$

Third, a statute may violate the text of the Constitution, but possibly not its spirit. This may describe the line-item budget veto, a legislative provision that allowed the President to cancel individual appropriations in the name of budget balancing. ${ }^{136}$ The line-item veto violates the text of the Constitution by forgoing the legislative process of presenting an entire bill to the President to be signed or vetoed. However, it arguably does not violate the spirit of the Constitution given the amount of budgetary and spending latitude the President already exercises consistent with his executive power. ${ }^{137}$

Similarly, actions can violate the text of the Constitution but not violate its spirit. For example, President Lincoln believed that he had an obligation to save the Union, including taking actions that might appear unconstitutional. 138

133. See N.Y. Times Co. v. Sullivan, 376 U.S. 254, 276 (1964) (discussing the Sedition Act: "These views reflect a broad consensus that the Act, because of the restraint it imposed upon criticism of government and public officials, was inconsistent with the First Amendment.").

134. See BRUFF, supra note 1 , at 169 (discussing the Tenure of Office Act); Curtis A. Bradley \& Trevor W, Morrison, Historical Gloss and the Separation of Powers, 126 HARV. L. REV. 411, 477-78 (2012) (discussing President Johnson and Tenure of Office Act).

135. The nature of the vesting clause is in dispute. See Bradley \& Morrison, supra note 20, at 1104 (noting that some claim that the executive power vesting clause "implicitly grants the President a broad range of powers" and that some disagree, but ultimately suggesting that the dispute "highlights the text's lack of specificity").

136. For a discussion of the line-item veto and its demise, see Clinton v. City of New York, 524 U.S. 417 (1998).

137. For a discussion of the power the President may exercise in budget matters, see Chambers \& Logue, supra note 51.

138. See BRUFF, supra note 1, at 120 (quoting Lincoln's willingness to "violate 
Conversely, actions that may be allowed by the Constitution may be used in a manner that violates its spirit. For example, the Senate's filibuster is presumptively constitutional because it flows from the Senate's explicit power to make its own rules. ${ }^{139}$ However, it can be used to functionally require a supermajority to pass legislation and to defeat the principle of majority rule that is arguably embedded in the Constitution. ${ }^{140}$

Whether unconstitutionality should be defined narrowly as text-bound or broadly as principles-based may depend on whether the Constitution is a legal document or a political document. Text-bound unconstitutionality is more sensible if the Constitution is a legal document, even one with embedded political principles. Identifying statutes that are unconstitutional by reference to direct text should be very rare. Such statutes would appear to stem from either congressional inability to read constitutional text or a congressional unwillingness to accede to the text's clear implications. Principles-based unconstitutionality is more sensible if the Constitution is primarily a political document with legally enforceable rules. However, principles-based unconstitutionality can be consistent with interpreting a legal document that has political principles embedded in it. If the interpretation's focus is on what the document means rather than on merely what it says, the reliance on principles to explain unclear or ambiguous text would amount to principlesbased unconstitutionality in the context of interpreting a legal document.

A narrow, text-based vision of unconstitutionality does not necessarily narrow the President's power to interpret the Constitution. A President can aggrandize power under either a broad or narrow view of unconstitutionality. Few presidential actions may be unconstitutional under a text-based view of

the Constitution, if necessary, to save the Union").

139. See U.S. ConST. art. I, $\S 5$ (allowing each house of Congress to control its own proceedings). The filibuster is the result of the Senate's standing rules, which allow unlimited debate. Senate Rule XXII provides that cloture may be invoked, with time limits set on the remainder of the debate, if sixty senators agree. For a fuller discussion, see Catherine Fisk \& Erwin Chemerinsky, The Filibuster, 49 STAN. L. REV. 181 (1997).

140. See BALKIN, supra note 103 , at 15 ("The principle of democracy ... is nowhere specifically mentioned in the constitutional text, and yet it may be the most frequently articulated principle in constitutional argument."); Fisk \& Chemerinsky, supra note 139, at 239-45 (discussing the filibuster and majoritarian constitutional values). 
unconstitutionality. That may give the President latitude to act or decline to act as he wishes, though it also expands Congress's latitude to check the President. ${ }^{141}$ Conversely, a principles-based unconstitutionality may render more presidential actions unconstitutional. However, it also may render more attempts to narrow executive power unconstitutional.

Some might suggest that all constitutional interpretation should be text-based, resulting in interpretive limits on all constitutional actors, including the President. ${ }^{142}$ However, the Constitution has already been interpreted in a principlesbound manner. ${ }^{143}$ Indeed, some judges who claim to believe in a text-bound unconstitutionality appear to deem some statutes unconstitutional when they violate the spirit, but not the text, of the Constitution. ${ }^{144}$ Not surprisingly, who should interpret the Constitution is as important as how the Constitution should be interpreted.

\section{E. Who Interprets the Constitution}

Who should interpret the Constitution is a key question that relates to what kind of document the Constitution is. If the Constitution is a legal document, constitutional interpretation arguably should primarily be a search for enforceable legal meaning engaged in by courts, even if some constitutional text may be unenforceable. ${ }^{145}$ The Supreme Court should have the

141. However, it is unclear whether Congress is in a position or of the mindset to check the President on issues of international law. See Jean Galbraith, International Law and the Domestic Separation of Powers, 99 VA. L. REV. 987, 988-89 (2013) (suggesting congressional unwillingness to check the President in foreign policy arena); David H. Moore, Taking Cues from Congress: Judicial Review, Congressional Authorization, and the Expansion of Presidential Power, 90 NotRE DAME L. REV. 1019, 1044 (2015); see also Dino P. Christenson \& Douglas L. Kriner, Political Constraints on Unilateral Executive Action, 65 CASE W. RES. L. REV. 897, 900-01 (2015) (suggesting that weak controls on the President from Congress and the Supreme Court suggest that Presidents ought to act unilaterally more often than they do).

142. See Jonathan T. Molot, The Rise and Fall of Textualism, 106 CoLUM. L. REV. 1, 30-36 (2006) (discussing textualism and its adherents).

143. See, e.g., Zivotofsky v. Kerry, 135 S. Ct. 2076 (2015); Obergefell v. Hodges, $135 \mathrm{~S}$. Ct. 2584 (2015) (finding freedom to engage in same-sex marriage in the Fourteenth Amendment despite the absence of text on the issue).

144. See, e.g., Shelby Cty. v. Holder, 133 S. Ct. 2612 (2013).

145. Some of the Constitution's language arguably does not create enforceable rights either because the language suggests a political question with a political solution or because the language is not intended to be enforceable. See Ryan C. 
last word on the meaning of the legal document. Other constitutional actors-including the President-may interpret the document, but their interpretation should be of little legal moment. Conversely, if the Constitution is considered a political document, Congress and the President arguably should have broad latitude to interpret it. The Supreme Court would still have the last word on constitutional interpretation when such interpretation is necessary to decide a case. In addition, courts would continue to interpret the Constitution's legally enforceable rules. However, other constitutional actors would be free to interpret the Constitution and act on their interpretation. Congress and the President could view the Constitution as suggesting principles of law that should guide action rather than as legal text that commands particular action.

The bigger and unsolvable problem is that the Constitution may appear to be a legal document to the courts and appear to be a political document to the other branches. In the hands of a court, the Constitution could be considered a legal document that sets specific barriers when it is clear, but sets no barriers when not clear. Conversely, in the hands of other constitutional actors, the Constitution could be considered a political document that sets a few specific barriers, but primarily presents the principles by which the government is supposed to run. Which group is correct is a political and philosophical issue to be resolved-slowly, if at all-by the three branches of the government and the citizenry through discussion, litigation, and elections. ${ }^{146}$

Constitutional interpretation is an iterative process through which the President and other constitutional actors guide the Constitution's meaning, and the Constitution's meaning guides the constitutional actors. ${ }^{147}$ Over time, accepted interpretations may not hew terribly closely to the

Williams, The Ninth Amendment as a Rule of Construction, 111 COLUM. L. REV. 498 (2011) (arguing that the Ninth Amendment is merely a rule of construction). But see Brian C. Kalt, The Ninth Amendment in Congress, 40 PEPP. L. REV. 75, 76-77 (2012) (suggesting substantive rights may be embedded in the Ninth Amendment).

146. See Nelson, supra note 96, at 546 (discussing Ronald Dworkin's theory that the Constitution may enshrine principles that may morph when applied to different situations over time).

147. See id. at 526-28 (noting that some framers envisioned an iterative process of constitutional interpretation would not always rely on judicial decision making). 
text. Nonetheless, those interpretations may serve the country well. In those contexts, the text arguably need not constrain presidential constitutional interpretation, even if the Constitution remains a legal document. However, even if each branch is allowed some latitude to interpret the Constitution, the effects of their interpretation may be limited by how their fellow coequal constitutional actors interpret the Constitution.

\section{DEPARTMENTALISM AND JUDICIAL REVIEW}

Departmentalism is "the theory that each of the three branches has the right-and the obligation-to interpret the Constitution for itself." 148 It rests on a strong vision of separation of powers that gives the President the responsibility to interpret the Constitution for the executive branch. 149 Departmentalism demands presidential constitutional interpretation and arguably encourages aggressive presidential constitutional interpretation. A President may defer to other branches with respect to constitutional interpretation, but departmentalism provides support for aggressive constitutional interpretation.

The scope of the President's latitude to interpret the Constitution and to act on her interpretation may depend on the scope of the duty or right of coequal constitutional branches to interpret the Constitution. ${ }^{150}$ Members of Congress and the Supreme Court must take oaths to support the Constitution. ${ }^{151}$ Congress should interpret the Constitution to ensure that legislation it passes is constitutional. ${ }^{152}$ The judiciary must

148. BRUFF, supra note 1 , at 65 ; see also Kelley, supra note 3 , at 79 (noting President Reagan's championing of departmentalism).

149. For a defense of departmentalism, see THE FEDERALIST NO. 49 (James Madison).

150. See CoOper, supra note 15, at 224 ("The fact that Presidents, like other constitutional officers, should be concerned about the constitutionality of their actions does not mean that they have a definitive authority to pronounce on the constitutionality of the actions of other institutions or to define the boundaries of their own authority."). An aggressive use of signing statements to claim the right to decline to execute laws can be problematic. See PFIFFNER, supra note 4 , at 208 ("[A]lthough there are legitimate uses of signing statements, their systematic use to expand Presidential authority or to justify the refusal of the President to execute the laws faithfully presents a threat to the separation of powers system and the constitutional balance among the three branches.").

151. See U.S. CONST. art. VI.

152. United States Senators and Representatives must, on oath or affirmation, promise to support the Constitution. Id. 
interpret the Constitution when determining the applicability of statutes. 153 The Supreme Court's and Congress's interpretations of the Constitution arguably bind the President and limit his interpretation of the Constitution. However, the limitation may be much less robust than it appears at first glance.

\section{A. The Scope of Congressional Constitutional Interpretation}

Departmentalism suggests that Congress should interpret the Constitution. Though members of Congress have an obligation to pass only those laws that they believe are constitutional, Congress may unintentionally pass unconstitutional laws. That possibility has been recognized since the country's founding. ${ }^{154}$ Congress's belief that a law it has passed is constitutional need not bind the President to treat the law as constitutional. If one of the implications of departmentalism is that each branch is supposed to make independent judgments regarding constitutional interpretation, congressional constitutional interpretation should not necessarily limit the President's constitutional interpretation.

Congress and the President are coequal constitutional actors. ${ }^{155}$ Neither is a court, and neither has a stronger claim to being able to divine constitutional meaning. Consequently, the President may have no obligation to presume that a law is constitutional merely because Congress believes it to be constitutional. The President may, as a matter of respect, consider Congress's views when determining whether a law is constitutional. However, Congress's belief that a law is constitutional need not bind the President if the President has an independent obligation to assess a law's constitutionality based on the presidential oath of office. Indeed, that oath may require that the President stop executive branch officials from executing laws he believes to be unconstitutional. ${ }^{156}$

153. Federal judges must, on oath or affirmation, promise to support the Constitution. See id.

154. See THE FEDERALIST No. 78, at 466-68 (Alexander Hamilton) (discussing judicial review of legislation).

155. The Constitution does not make one the superior of the other. See U.S. CONST. art. I, II.

156. See PFIFFNER, supra note 4, at 211-14 (discussing how signing statements 


\section{B. The Scope of the Supreme Court's Constitutional Interpretation}

How departmentalism meshes with judicial review is trickier. If judicial review means anything, the Supreme Court should be the last word on the Constitution's meaning. The Court's judgments must be followed; its interpretation of the Constitution arguably binds the President and Congress. ${ }^{157} \mathrm{~A}$ Supreme Court decision can bind the other branches in one of three ways. First, the executive may be bound by the Supreme Court's constitutional interpretation when that interpretation is embedded in a judgment the executive must enforce. ${ }^{158}$ The Court has the duty, based on its oath to support the Constitution, to decline to issue a judgment based on an unconstitutional law. However, the Supreme Court's interpretive supremacy could be limited only to the cases before it. 159 The Supreme Court is responsible for deciding cases, but arguably does not have the right to be the last word on cases not in front of it. 160 Indeed, Presidents may be unwilling to follow Supreme Court rulings any further than required by the Court's decision. ${ }^{161}$

Second, the Court's opinion on a statute's constitutionality

can, should, and should not be used to guide executive branch officials).

157. Some argue that should not be the case. See Jeremy Waldron, The Core of the Case Against Judicial Review, 115 YALE L.J. 1346, 1348 (2006) ("This Essay will argue that judicial review of legislation is inappropriate as a mode of final decisionmaking in a free and democratic society.").

158. However, presidential recalcitrance or threats to decline to enforce judgments or abide by court decision can be problematic. See BRUFF, supra note 1, at 255 (discussing the German saboteurs case in which President Franklin Roosevelt made clear that he would resist a writ of habeas corpus and guarantee that the saboteurs would be tried by a military commission).

159. However, the Court's decision certainly binds the parties. See EPPS, supra note 90, at $\mathrm{x}$-xi (citing President Lincoln's first inaugural address and its suggestion that a Supreme Court case binds the parties and is entitled to respect, but ought still be questioned by the people).

160. The Supreme Court's decision arguably binds only the lower federal courts. See Richard H. Fallon, Jr., As-Applied and Facial Challenges and ThirdParty Standing, 113 HARV. L. REv. 1321, 1339-40 (2000). However, that may effectively bind the other branches if cases are easy to bring based on the unconstitutional law.

161. See Prakash, supra note 9, at 1621 ("[T]here is a rich literature describing the Executive Branch practice of non-acquiescence-that is, a decision to enforce a court's judgment in favor of a particular party coupled with a refusal to employ the court's rationale in future cases."); see also EPPS, supra note 90, at x ("[A Supreme] Court decision resolves a specific dispute among specific parties at a specific time. What it does not do is end the debate."). 
could be thought to apply in other legally similar cases or situations. ${ }^{162}$ Under this view, the President and Congress should acquiesce to the Court's interpretation in cases that would seem to be governed by the Court's opinion, not merely because those cases likely would be decided in the same way as the prior case, but because the Court has been deemed the expositor of constitutional law. Presumably, the Supreme Court's decisions should apply not only to lower federal courts that will decide future similar cases, but to the country. ${ }^{163}$ However, the President and Congress might retain the latitude to ignore the implications of the Court's decision and apply the unconstitutional statute in situations that the President and Congress believe to be legally distinct from the situations underlying the precedential cases the Court has already decided.

Third, a Supreme Court opinion could be thought to render the unconstitutional law void, with the President and Congress unable to apply the statute in any circumstance. ${ }^{164}$ The President and Congress would be bound by the Court's opinion. However, even under this strongest form of judicial supremacy, Congress and the President may continue to pass legislation that appears to be unconstitutional under the Court's decision. ${ }^{165}$ Of course, federal courts would be ready to deem such laws unconstitutional in relevant cases.

\section{Implications}

Departmentalism suggests that the President should interpret the Constitution for the executive branch. However,

162. See Prakash, supra note 9, at 1623 (suggesting that President may be willing to take the Court's decision regarding constitutionality of legislation and apply it in similar circumstances).

163. Sometimes Congress ignores Supreme Court decisions. For example, Congress has continued to insert legislative veto provisions even though the Court deemed the legislative veto unconstitutional in I.N.S. v. Chadha, 462 U.S. 919 (1983). See COOPER, supra note 15, at 209-10.

164. See Marbury v. Madison, 5 U.S. (1 Cranch) 137, 180 (1803) ("Thus, the particular phraseology of the constitution of the United States confirms and strengthens the principle, supposed to be essential to all written constitutions, that a law repugnant to the constitution is void; and that courts, as well as other departments, are bound by that instrument.").

165. Congress essentially ignored the Dred Scott decision when it passed legislation freeing slaves in the territories during the Civil War. See Henry L. Chambers, Jr., Lincoln, The Emancipation Proclamation, and Executive Power, 73 MD. L. REV. 100, 112 n.91 (2013). 
the President may have an obligation to act with restraint when interpreting the Constitution. ${ }^{166}$ Presidential constitutional interpretation is a necessary exercise in a departmentalist system, but presidential constitutional interpretation arguably should be more conservative than judicial review. If the courts have primary responsibility for determining the Constitution's meaning, the President should not interpret the Constitution in a manner that is inconsistent with the Supreme Court's interpretive role. ${ }^{167}$ A text-based approach to constitutional interpretation may be appropriate, with the President presuming the constitutionality of legislation whenever such legislation is arguably constitutional, but may not be realistic.

Even if a President adopts a conservative view on constitutional interpretation, broader latitude may be appropriate when addressing congressional infringement on executive power. Legislation that relates to or curtails executive power might trigger the need for the President to interpret the Constitution even without Supreme Court approval. 168 The Constitution vests the executive power of the United States in the President. ${ }^{169}$ Defending executive prerogative from legislative branch encroachment even in the absence of a judgment by the Supreme Court seems reasonable. ${ }^{170}$ Indeed, the President may have a special obligation to address legislation that limits executive power.

166. Conversely, the President and Congress might be thought to have the same power to interpret the Constitution as the Supreme Court. See Prakash, supra note 9, at 1644 (" $[\mathrm{E}]$ arly constitutional interpretation was utterly dominated by the Executive and Legislative Branches, with the Judiciary playing a minor, episodic role.").

167. The courts believe they have that responsibility. See Marbury, 5 U.S. (1 Cranch) at 177 (noting that interpreting the Constitution is the Court's function). However, some might cabin that authority. See Prakash, supra note 9, at 1674 (suggesting that coequal constitutional branches should not have to defer to the judiciary: "It is one thing to consult and respectfully consider the constitutional wisdom offered by another branch; it is another to tether the President (or Congress) to the Judiciary's constitutional pronouncements.").

168. This may be necessary if the courts decline to police interbranch disputes, claiming that they trigger political questions. See, e.g., Bradley \& Morrison, supra note 20 , at 1109-10 (suggesting that courts often decline to police disputes between legislative and executive branches in areas involving foreign policy).

169. U.S. CONST, art. II, § 1.

170. However, a President can go too far. See PFIFFNer, supra note 4, at 227 ("II]f the President maintains that Presidential executive authority and the commander-in-chief clause can overcome virtually any law that constrains the executive, then the executive is claiming unilateral control of the laws."). 
Such action would police the Constitution's separation of powers structure and might be particularly sensible, as a law that limits executive authority may be unlikely to be reviewed by the courts unless the President challenges it.

What to do when the legislative branch has supposedly infringed on executive prerogative is an ongoing source of friction. A perceived infringement is at the core of Zivotofsky $v$. Kerry, the subject of the last part of this Article. In that case, the Court did not decide where the line between executive prerogative and legislative power should be drawn or how the President and Congress should police it, but it did consider the issue. In the process, the Zivotofsky Court indirectly commented on how the President may be allowed to interpret the Constitution.

\section{ZIVOTOFSKY V. KERRY}

Zivotofsky $v$. Kerry ${ }^{171}$ provides a vehicle for considering aggressive presidential constitutional interpretation. In Zivotofsky, the Court decided a dispute between the President and Congress regarding which branch had the authority to determine how a passport holder's place of birth would be listed on an American passport. ${ }^{172}$ Executive branch policy required that if the passport holder was born in Jerusalem, Jerusalem (not Israel) would be listed as the passport holder's place of birth. 173 The regulation stemmed from the United States' longstanding refusal to recognize Israeli sovereignty over Jerusalem. ${ }^{174}$ As a part of the Foreign Relations Authorization Act, Fiscal Year 2003, Congress passed a provision requiring that if an American passport holder born in Jerusalem so requested, the holder's passport would list Israel as the holder's place of birth. ${ }^{175}$ President George W. Bush signed the legislation, but issued a signing statement indicating that he would interpret the legislation to give the President the discretion to list Jerusalem or Israel as the passport holder's place of birth. ${ }^{176}$ The signing statement noted that if the

171. 135 S. Ct. 2076 (2015).

172. Id. at 2081.

173. Id. at 2082 .

174. Id. at 2081.

175. Id. at 2082.

176. The President did not argue that the entire provision was unconstitutional. Id. The President argued that a particular interpretation of the 
legislation dictated how the holder's place of birth would be listed on the passport, it unconstitutionally trenched on the President's authority to determine which countries the United States recognizes. ${ }^{177}$ Without focusing on the signing statement or its appropriateness, the Court resolved the dispute in a manner that suggests that executive power should be construed based on constitutional principle as much as on constitutional text. ${ }^{178}$ That may suggest that the President acts appropriately when he interprets executive power under the Constitution based on constitutional principles rather than on constitutional text. In turn, that may influence how and how often Presidents craft constitutional signing statements and act on the interpretation of the Constitution embedded in those signing statements.

\section{A. The Case}

Zivotofsky addressed the President's authority to recognize foreign countries and Congress's right to limit that authority. ${ }^{179}$ The United States has recognized Israel since 1948. ${ }^{180}$ However, the recognition power includes the power to recognize the bounds of another country's territorial sovereignty. ${ }^{181}$ Thus, congressional action that requires the President to contradict his determination regarding another country's sovereign borders is unconstitutional. ${ }^{182}$ Congress's

text was unconstitutional. That could be considered a cop-out in context given that 1) the provision's proper interpretation is clear and is contrary to the President's interpretation, and 2) there was little reason for Congress to pass the particular provision unless it was intended to be proscriptive. Id. ("[Section] 214 (d) states '[f]or purposes of the registration of birth, certification of nationality, or issuance of a passport of a United States citizen born in the city of Jerusalem, the Secretary shall, upon the request of the citizen or the citizen's legal guardian, record the place of birth as Israel."').

177. Id.

178. See id. at 2091 (using text, precedent and constitutional practice to resolve the issue).

179. Id. at 2081 ("The Court addresses two questions to resolve the interbranch dispute now before it. First, it must determine whether the President has the exclusive power to grant formal recognition to a foreign sovereign. Second, if he has that power, the Court must determine whether Congress can command the President and his Secretary of State to issue a formal statement that contradicts the earlier recognition."). For a fuller discussion of the facts of Zivotofsky, see Goldsmith, supra note 23 .

180. Zivotofsky, 135 S. Ct. at 2096.

181. Id.

182. Id. 
attempt to require that Americans born in Jerusalem be given the option to list Israel as their place of birth on American passports was deemed unconstitutional. ${ }^{183}$ The President has the exclusive authority to recognize foreign countries and, therefore, must have the latitude to decide precisely how the birthplace of a U.S. citizen born in Jerusalem will be listed on that person's U.S. passport. ${ }^{184}$

The Court began its analysis by referencing Youngstown Sheet \& Tube Co. v. Sawyer ${ }^{185}$ and the familiar proposition from Justice Jackson's Youngstown concurrence suggesting that when the President and Congress disagree about the presidential constitutional authority to take an action, the President must have the exclusive authority to take the contemplated action for that action to be constitutional. 186 Though the Youngstown structure is a gloss on the Constitution, ${ }^{187}$ it arguably flows sensibly from the separation of powers doctrine that undergirds the Constitution. ${ }^{188}$

The Constitution does not explicitly give the President the sole authority to recognize foreign nations. ${ }^{189}$ The Court noted that "[n]o single precedent resolved whether the President has exclusive recognition authority and, if so, how far that power extends." 190 However, the Court recognized that the Reception Clause could be interpreted, based on history, past practice, and other Article II text, to provide the President with the sole authority to recognize foreign countries. ${ }^{191}$ The Court recognized that Congress could use its legislative powers to

183. Id.

184. Id. at 2095 (noting that Congress cannot force the President to contradict operative executive policy on recognition of foreign country).

185. 343 U.S. 579 (1952).

186. Zivotofsky, 135 S. Ct. at 2083-84; see also Fallon, supra note 41 , at 355 (noting "the widespread acknowledgement that Justice Jackson's Youngstown concurrence provides the framework for analysis of Presidential power").

187. That gloss, which focuses on whether Congress has authorized the President to act, may create an additional gloss in interpreting the scope of executive power. See Moore, supra note 141, at 1020 ("Under the analysis emanating from Justice Frankfurter's Youngstown concurrence, the Court may find that a history of congressional authorization has produced a gloss on the executive power vested in the President.").

188. Justice Jackson's Youngstown concurrence provides a functional allocation of power between the legislative and executive branches. See Chambers, supra note 165 , at 120 n.144.

189. Zivotofsky, 135 S. Ct. at $2084-85$.

190. Id. at 2088 .

191. Id. at 2091-94. 
influence the President in his exercise of the recognition power, but ruled that Congress could not directly impinge on the executive's recognition power. ${ }^{192}$

However, deeming the President to have the sole power to recognize foreign nations was not sufficient to resolve the case. ${ }^{193}$ The Court had to determine whether the legislation that Congress passed and that the President signed constituted an infringement on the President's recognition power. ${ }^{194}$ The Court determined that the legislation at issue did infringe the recognition power by requiring that the executive branch contradict executive branch policy on neutrality toward Israel's sovereignty over Jerusalem. ${ }^{195}$ In passing legislation that directly contradicted the President's decision to continue to decline to recognize Jerusalem as within Israel's sovereign boundaries, Congress violated the Constitution. ${ }^{196}$

\section{B. Zivotofsky, Constitutional Text, and Constitutional Principles}

Zivotofsky is particularly important because it focused more on constitutional principles than on constitutional text. ${ }^{197}$ This is not a surprise or a criticism. The Constitution includes text that is more than two centuries old. Much of that text has already been interpreted. Consequently, interpreting constitutional text often depends more on determining whether the text's non-obvious meanings are consistent with the principles that the Court believes underlie the Constitution than straightforwardly interpreting the text for its obvious meaning. ${ }^{198}$ Considering constitutional principles rather than relying solely on text is a reasonable method of interpreting the Constitution. ${ }^{199}$ Such interpretation is text-based, but may not be considered strictly textual. ${ }^{200}$ The Zivotofsky Court took that

192. Id. at 2087.

193. Id. at 2094 .

194. Id.

195. Id.

196. Id. at 2095 .

197. Id. at 2091 (noting that the Court considered constitutional text, precedent and "accepting understandings and practice" to determine issue).

198. For a robust discussion of the non-use of constitutional text in constitutional interpretation, see Strauss, supra note 19.

199. See Chambers, supra note 87 , at 109.

200. See Chambers, supra note 95 , at $636-37$ ("Most interpreters would claim to be text-based. However, there is a difference between asserting that text 
approach.

Various principles derived from constitutional text undergird the Zivotofsky decision. The Court suggested that Justice Jackson's Youngstown structure accurately represents the Constitution's approach to separation of powers; ${ }^{201}$ that the United States must speak with one voice regarding certain foreign policy issues, notwithstanding shared power between Congress and the President in the foreign policy area; 202 and that the President has primary authority to speak for the United States on certain issues. ${ }^{203}$ The need to rely heavily on principle rather than text may help explain why Justice Breyer suggested that the issue in this case is a political question that should have been left to the political branches to resolve. ${ }^{204}$ Fundamentally, Zivotofsky relied on constitutional principles rather than purely on constitutional text to determine the subject legislation's constitutionality. That approach may have important implications for how presidents may interpret the Constitution.

\section{Implications}

Zivotofsky endorses a method of constitutional analysis that encourages broad executive power. ${ }^{205}$ The Court found that the President has inherent power in foreign policy matters based on general principles of constitutional law, rather than based solely on constitutional text. ${ }^{206}$ By focusing as much on constitutional principles and historical practice as on constitutional text, the Court's approach may suggest that presidential constitutional interpretation may also focus more on constitutional principles and historical practice than on constitutional text. ${ }^{207}$ The Zivotofsky Court decided the case in

\footnotetext{
matters and focusing almost solely on text to reveal its meaning.").

201. Zivotofsky, 135 S. Ct. at 2083-84.

202. Id. at 2090 ("The Executive is not free from the ordinary controls and checks of Congress merely because foreign affairs are at issue.").

203. Id. at 2095.

204. Id. at 2096 (Breyer, J., concurring) ("I continue to believe that this case presents a political question inappropriate for judicial resolution.").

205. See SHANE, supra note 2, at 114-21 (discussing expansion of executive power by unreviewable executive branch interpretations of law).

206. Zivotofsky, 135 S. Ct. at 2091.

207. See id. (demonstrating the Court's use of constitutional text, precedent, and accepted executive practices to resolve the matter of presidential constitutional interpretation).
} 
a manner that may suggest that Presidents ought to have wide-ranging power to interpret the Constitution and act on those interpretations. ${ }^{208}$

By reading the Constitution as it did, the Zivotofsky Court supports the argument that the executive's power is nearly supreme in certain areas of foreign policy. ${ }^{209}$ The Court encourages the President to read the Constitution broadly and aggressively in the foreign policy area and in other areas involving executive power. ${ }^{210}$ In the wake of Zivotofsky, the President arguably should have the latitude to resist congressional mandates in almost any situation where he might be called by Congress to contradict himself on a policy matter that is given to him to decide. That may create more interbranch disputes. The Supreme Court's inability or unwillingness to solve certain interbranch disputes may create a power struggle between the political branches that must be resolved by politics. ${ }^{211}$ That may be the preferred method of constitutional interpretation and resolution whenever constitutional interpretation veers away from pure text-based interpretation and toward principles-based interpretation. However, there is a danger that both the executive and legislative branches will eventually use self-help. ${ }^{212}$

Presidential self-help could take the form of additional constitutional signing statements. A strong vision of the executive power vesting clause might lead to a vision of the unitary executive that would seem to provide a sufficient

208. See id. at 2095-96.

209. Id. at 2089 (noting that the President has sole power to recognize foreign countries).

210. Arguably, the executive branch already does that. See SHANE, supra note 2 , at 113 (suggesting that the executive branch tends to read the Constitution as broadly as possible-to its "furthest analytically plausible limit"-when it interprets executive power under the Constitution).

211. See Bradley \& Morrison, supra note 134, at 430 ("More generally, dismissals on political question grounds can be understood as a form of judicial underenforcement of the Constitution. On that understanding, the only difference between political question dismissals and deference to historical practice may be the extent of the deference. In either case, the judiciary places the constitutional answer substantially in the hands of the political branches.").

212. Of course, the executive may always use self-help. See Kelley, supra note 3 , at 86 ("The Presidential signing statement, in all of its forms, will continue to play a role in future presidencies because it enables the President to win battles that he may not be able to win in the normal course of the legislative process. The strategic use of the signing statement also demonstrates the importance of the executive's aggressive constitutional interpretation when the tools of the modern presidency break down."). 
constitutional basis on which to rest a constitutional signing statement pledging resistance to any congressional mandate affecting executive power. ${ }^{213}$ Constitutional signing statements challenging Congress's asserted interference with executive power would seem particularly appropriate. As important, constitutional signing statements might be appropriate in other areas that concern or define executive power. The Zivotofsky opinion suggests that the scope in which the President can claim primary authority to act is broad, making constitutional signing statements in such areas more appropriate than they might seem otherwise. Given that some limits on executive power may be less likely to be challenged unless the executive branch challenges them, issuing constitutional signing statements and waiting for Congress or others to challenge the interpretation embedded in the signing statements may make practical sense.

The President's general approach to constitutional signing statements arguably should be to push presidential constitutional interpretation as far as possible to provide precedent for pushing presidential constitutional interpretation as far as possible in the future. 214 Some may argue that this is not new because executive power has been expanding for more than two centuries, and that an attempt to limit it might be deemed revolutionary. 215 Nonetheless, Zivotofsky provides additional arguments for the further expansion of executive

213. Of course, what power the executive power vesting clause confers is a matter of dispute. See Moore, supra note 187, at 1049 ("[T] he meaning of the clause vesting executive power in the President . . . is hotly contested."); Strauss, supra note 42, at 1154 (noting the possibility that the executive power vesting clause need not be read as broadly as some read it).

214. Some have made that point with respect to signing statements. See COOPER, supra note 15, at 219-20 (noting that some have used prior presidential signing statements as precedent for new signing statements); SHANE, supra note 2, at 141-42 (noting that signing statements arguably have the effect of treating extreme presidential interpretation as the norm with the result that people can look to the signing statements as having some legitimate legal standing on their own); Goldsmith, supra note 23, at 143-44. For a comparison of the numbers of signing statements issued from the Hoover Administration through the beginning of the final year of the George W. Bush Administration, see PFIFFNER, supra note 4 , at 199 .

215. See Moore, supra note 141, at 1044 (noting that Congress may not be in the position to check the expansion of executive power); see also Bradley \& Morrison, supra note 20, at 1099 (noting that some scholars do not believe that the President is much constrained at all by law); Fallon, supra note 41, at 350 (referencing arguments that suggest politics, rather than law, may be all that currently constrains the President). 
power and self-help.

Of course, self-help could become harmful. The President may issue increasing numbers of constitutional signing statements with Congress possibly responding by claiming that all parts of a statute are nonseverable. ${ }^{216}$ That might make any decision regarding the constitutionality of a statutory provision a decision regarding the validity of the whole statute. ${ }^{217}$ That is not a palatable solution as it would bind the executive and the judiciary to the requirement that deeming any part of legislation unconstitutional would require jettisoning the remainder of the legislation. More importantly, it has the potential to invalidate legislation that is overwhelmingly beneficial to the country.

In the alternative, Zivotofsky may provide little help to a President who wants to act on a broad interpretation of the Constitution. Substantively, the Zivotofsky Court agreed with President Bush's interpretation that the statutory provision at issue was unconstitutional, but may not have agreed with President Bush's assumption that he could issue a signing statement and refuse to execute the law. ${ }^{218}$ A President may interpret the Constitution as broadly or as narrowly as the President wishes when generally opining on the content of the Constitution. However, whenever the President declines to enforce statutory law based on his interpretation of the Constitution, the President may have an obligation to wait until the federal courts interpret the Constitution or to interpret the Constitution in a manner that so closely follows its text that almost no one would disagree with the President's position. ${ }^{219}$ The Zivotofsky Court may have merely decided a

216. Severability and non-severability may be a function of congressional intent. See Regan v. Time, Inc., 468 U.S. 641, 653 (1984) (plurality opinion) ("Whether an unconstitutional provision is severable from the remainder of the statute in which it appears is largely a question of legislative intent, but the presumption is in favor of severability."); see also United States v. Booker, 543 U.S. 220, 259 (2005) (discussing severability).

217. Regan, 468 U.S. at 653.

218. See Zivotofsky v. Kerry, 135 S. Ct. 2076, 2096 (2015) (explaining that lawmaking still resides with the legislature and not the executive).

219. Some argue that federal courts should closely follow the text when interpreting the Constitution. See, e.g., Antonin Scalia, Common-Law Courts in a Civil-Law System: The Role of United States Federal Courts in Interpreting the Constitution and Laws, in A MATTER OF INTERPRETATION 3, 37-47 (Amy Gutmann ed., 1997) (arguing textualism and originalism as the proper modes of constitutional interpretation). Text-based analysis can come in many variations. See Chambers, supra note 95, at 637 ("[T]here is a difference between asserting 
case and clarified constitutional principles in the process. The case does not necessarily suggest that President Bush should have issued the signing statement at issue and defied the law. That issue relates to a President's presumed capacity to act on presidential constitutional interpretation. The problem, of course, is that the right to interpret the Constitution broadly suggests the right to act on that interpretation, particularly in situations in which a failure to act means the loss of executive power afforded by the Constitution.

\section{CONCLUSION}

The Constitution may provide the President the latitude to interpret the document aggressively and to act on the interpretation. The presidential oath and the Take Care Clause may encourage the President to interpret the Constitution before declining to enforce constitutionally suspect laws. ${ }^{220}$ The President may have an obligation to decline to enforce federal law that is clearly unconstitutional. However, the President presumably should reach that conclusion only if the statute clearly conflicts with the Constitution's text leaving more contested constitutional interpretation to the federal courts.

The tension between providing broad latitude and narrow latitude for the President to interpret the Constitution was addressed implicitly by the Supreme Court in Zivotofsky $v$. Kerry. The Zivotofsky Court's analysis of the President's recognition power did not hew closely to text. Rather, it was based on a mélange of text, precedent, and past practice. Arguably, that is how constitutional interpretation should work when resolving interbranch disputes.221 Fundamentally, constitutional interpretation is an iterative process through which the President, Congress, and the Supreme Court

that text matters and focusing almost solely on text to reveal its meaning.").

220. Of course, what the Take Care Clause demands is unclear. See Chambers, supra note 165, at 122-23 ("In the wake of the Court's limited discussions of the Take Care Clause, the Clause can be considered to provide both a duty requiring the Executive to enforce the law as the legislation demands and a license allowing the President to interpret statutes in the context of determining how to enforce them.").

221. See Bradley \& Morrison, supra note 134, at 412-13 ("Arguments based on historical practice are a mainstay of debates about the constitutional separation of powers. These arguments are especially common in debates over the distribution of authority between Congress and the executive branch.”); Strauss, supra note 19 , at 61 . 
interpret the Constitution, with the people eventually responding. ${ }^{222}$ Practically, presidential constitutional interpretation has strayed from the Constitution's text since the beginning of the Republic. ${ }^{223}$

In the wake of Zivotofsky, the President has little reason to stop claiming broad executive authority through constitutional signing statements. 224 The President exercises broad executive authority that Congress cannot infringe. That broad authority can be based on principles underlying the Constitution rather than based directly on clear text. Consequently, a constitutional signing statement may be the most appropriate tool for the President to use to force the resolution of murky constitutional issues. When there was reason to believe that the Supreme Court might cabin executive power, the use of a constitutional signing statement could be thought inappropriately aggressive. However, after Zivotofsky, a constitutional signing statement can be considered a placeholder for future litigation regarding the breadth of the President's executive authority.

Constitutional interpretation that is tied to constitutional principles rather than directly to constitutional text may be reasonably necessary to allow our Republic to continue to work. The President may need more executive authority than the U.S. Constitution originally contemplated, and the Constitution may need to embrace the full range of possible interpretations based on its text and the principles underlying it to make for a more perfect union. Concerns that Presidents ought to be limited in how they interpret the Constitution may have been justified at some point in the past. However, given how Presidents have interpreted the Constitution and how the Court would seem to allow the President the latitude to interpret the Constitution in certain areas, such as foreign policy, it may be well past time to claim that the President

222. See BRUFF, supra note 1 , at 457-58; see also PFIFFNER, supra note 4 , at 223 ("Legitimate or not, official presidential actions can become important precedents.").

223. Assertions of extratextual power have occurred since the Constitution was ratified. See Christenson \& Kriner, supra note 141, at 898 ("Bold assertions of unilateral presidential authority have been prominent features of the American political landscape almost since the Founding.").

224. Of course, that can be problematic according to some. See, e.g., Jackson, supra note 5 , at 15 ("The President's unbridled use of signing statements, stemming from his 'larger-than-life' view of presidential prerogative, has resulted in an expansion of executive power that challenges our balance of government."). 
should interpret the Constitution narrowly, hew close to constitutional text in doing so, and issue constitutional signing statements rarely. 
UNIVERSITY OF COLORADO LAW REVIEW 